\title{
ACTIVE POWER LOSS MINIMIZATION IN ELECTRIC POWER SYSTEMS THROUGH CHAOTIC ARTIFICIAL BEE COLONY ALGORITHM
}

\author{
Leyla Kuru, Ali Ozturk, Ersen Kuru, Serkan Cobanli
}

Original scientific paper

Reactive power optimization (RPO) is a major field of study to ensure power systems for operating in a secure and economical manner. RPO can be used for decreasing of active power losses, voltage control, and for the optimization of the power coefficients in power systems. The non-linear power loss function is used as an object function that will be minimized. In this study Chaotic Artificial Bee Colony (CABC) algorithm is used to minimize the active power loss of power systems. Chaotic maps such as logistic map and Henon map are used against the random number generator. CABC is applied on the IEEE6-bus and IEEE 30-bus test systems and the results are shown. Accordingly, the results have been evaluated and observed that the stability critical values found by $\mathrm{CABC}$ can be used to produce good potential solutions. Simulation results are promising and show the effectiveness of the applied approach.

Keywords: chaos; Chaotic Artificial Bee Colony; optimization; power systems

\section{Smanjenje gubitka aktivne snage u elektro-energetskim sustavima primjenom algoritma kaotične umjetne kolonije pčela}

Izvorni znanstveni članak Optimizacija reaktivne snage - Reactive power optimization (RPO) - osnovno je područje istraživanja u svrhu sigurnog i ekonomičnog rada energetskih sustava. RPO se može primijeniti za smanjenje gubitaka aktivne snage, reguliranje napona te za optimizaciju energetskih koeficijenata u energetskim sustavima. Funkcija ne-linearnog gubitka snage koristi se kao funkcija cilja koju treba smanjiti. U ovom se radu algoritam Kaotične umjetne kolonije pčela - Chaotic Artificial Bee Colony (CABC) - primjenjuje za smanjenje gubitka aktivne snage u energetskim sustavima. Rabe se kaotične mape kao što su logistička mapa i Henon mapa. CABS se primjenjuje na provjeravanim sustavima IEEE 6-sabirnice i IEEE 30-sabirnice i daju se rezultati. Provjerom rezultata ustanovilo se da primjena kritičnih vrijednosti stabilnosti dobivenih pomoću CABS može rezultirati dobrim potencijalnim rješenjima. Rezultati simulacije su obećavajući i pokazuju učinkovitost primijenjenog pristupa.

Ključne riječi: elektroenergetski sustavi; kaos; kaotična umjetna kolonija pčela; optimizacija

\section{Introduction}

Reactive power optimization (RPO) has a significant importance for voltage stability, voltage quality, and power losses in power systems. The total active power loss function is the object function of the system. This function is a non-linear function having many variables depending on many constraints $[1 \div 5]$. This problem is firstly solved by the classical methods such as linear, nonlinear, and quadratic dynamic mathematical algorithms. Subsequently intuitive methods have been used. RPO is realized by $\mathrm{Lu}$ and Ma neuro-dynamic programming [1]. Durairaj and Fox have applied evolutionary computation based RPO to 30 and 118 bus systems of IEEE [2]. Hazrai and Sinha have done active and reactive power optimization via particle swarm algorithm [3]. Li. et al. have used adaptive particle swarm algorithm [4]. Wei et al. and Chen et al. have used basic immunity in genetic algorithm (GA) and advance GA methods in RPO respectively $[5,6]$. Wang et al. have used cultivation simulation algorithm [7, 8]. Wei et al. have found optimum parameter values by using the method of germ [9]. Zhang et al. have reached the global minimum point by application based search algorithm [10]. Liu et al. have applied a hybrid optimization with taboo search and ordinal optimization methods [11]. Liu et al., Lenin, and Mohan have used ant colony in the solution of RPO problem $[12 \div 14]$. Liu et al. have applied adaptive genetic simulation annealing algorithm [15] and then Zhang and Lui have joined the literature by RPO with fuzzy logic controlled particle swarm algorithm [16]. Optimization of power systems has been investigated by many researchers. $[17 \div 20]$. One of the intuitive methods, ABC is an algorithm that reaches to global minimum by looking for the solution in the evolutionary way and that is inspired by the movements of the bees during the nectar search. $\mathrm{ABC}$ is an algorithm incorporated to the literature by Karaboğa in 2005. This algorithm is used for the optimization of many non-linear problems in a short time slice $[21 \div 30]$.

Lots of chaotic maps in the literature possess certainty, ergodicity and the stochastic property. Recently, chaotic sequences have been adopted instead of random sequences and good results have been shown in many applications. They have also been used together with some heuristic optimization algorithms (Alatas, Akin, \& Ozer, 2009; Coelho \& Mariani, 2008) [31, 32] to express optimization variables. The choice of chaotic sequences is justified theoretically by their unpredictability, i.e., by their spread-spectrum characteristic, non periodic, complex temporal behavior, and ergodic properties. Alatas has proposed $\mathrm{ABC}$ algorithms using chaotic maps [33]. In this study Chaotic Artificial Bee Colony algorithm $(\mathrm{CABC})$, is used to minimize the active power loss of power systems. Chaotic maps such as logistic map and Henon map are used against the random number generator.The CABC algorithm for solving RPO has been solved for IEEE 6-bus system and IEEE 30-bus system. The CABC algorithm is compared with clasiccal ABC algorithm. It is shown by the results that active power losses can be decreased by CABC algorithm.

\section{Reactive power optimization}

The goal of RPO is to minimize the active power losses by changing the generator bus voltages, reactive 
power value of the capacitors connected to the system, and the level modifier values of the transformers. Active power losses are expressed in equation 1 where $P_{\text {loss }}$ is the total active power loss, $N_{\mathrm{E}}$ is the number of distribution lines, $\mathrm{g}_{\mathrm{k}}$ is the conductance of the line connecting $i$ and $j$ bus, $V_{i}$ is the voltage of the $i^{\text {th }}$ bus, $V_{j}$ is the voltage of the $j^{\text {th }}$ bus, $\varphi_{i j}$ is the phase angle of the voltage value between $i$ and $j[1 \div 16]$ :

$$
\begin{aligned}
& \min f_{Q}=\sum_{k \in N_{\mathrm{E}}} P_{\text {loss }} \\
& \min f_{Q}=\sum_{k \in N_{\mathrm{E}}} g_{k}\left(V_{i}^{2}+V_{j}^{2}-2 V_{i} V_{j} \cos \varphi_{i j}\right) .
\end{aligned}
$$

Power balance equality constraints known from power flow equations are given in Eqs. (2) and (3) where $\delta_{i}$ and $\delta_{j}$ are the angle of voltage value of the $i^{\text {th }}$ and $j^{\text {th }}$ bus respectively. $N_{\mathrm{B}}$ is the total number of buses, $P_{\mathrm{G} i}$ and $Q_{\mathrm{G} i}$ are the active and reactive power of the generator respectively. $P_{\mathrm{D} i}$ and $G_{\mathrm{D} i}$ are the demanded active and reactive powers. $G_{i j}$ and $B_{i j}$ are the conductance and suceptance value between the $i$ and $j$ buses.

$$
\begin{aligned}
& P_{G i}-P_{D i}-V_{i} \sum_{j=1}^{N B} V_{j}\left[\begin{array}{l}
G_{i j} \cos \left(\delta_{i}-\delta_{j}\right)+ \\
B_{i j} \sin \left(\delta_{i}-\delta_{j}\right)
\end{array}\right]=0 \\
& Q_{G i}-Q_{D i}-V_{i} \sum_{j=1}^{N B} V_{j}\left[\begin{array}{l}
G_{i j} \sin \left(\delta_{i}-\delta_{j}\right)+ \\
B_{i j} \cos \left(\delta_{i}-\delta_{j}\right)
\end{array}\right]=0
\end{aligned}
$$

The variation interval of the variables is given in Eqs. (4), (5), (6), and (7). Where $T_{k}$ is the transformer tap changer $Q_{C}$ is the reactive power compansator:

$$
\begin{aligned}
& V_{i \text { min }} \leq V_{i} \leq V_{i \max }, \\
& Q_{G_{i \min }} \leq Q_{G_{i}} \leq Q_{G_{i \max }}, \\
& T_{k \text { min }} \leq T_{k} \leq T_{k \max }, \\
& Q_{C_{i \min }} \leq Q_{C_{i}} \leq Q_{C_{i \max }}
\end{aligned}
$$

\section{Artificial Bee Colony (ABC)}

$\mathrm{ABC}$ algorithm has been inspired by the intelligent behavior of reel bees while they are searching for nectar recources and sharing them with other bees $[21 \div 26]$. The artificial bee colony consists of three kinds of bees named as employed, onlooker, and scouts. Each sort of them differs from their role in the optimization process. Employed bees staying over the nectar source hold the neighboring sources in mind. Onlooker bees recieve this information from employed bees and make a resource selection to gather the nectar. The scout bees are also responsible for finding new nectar resources. The algorithm has three steps. The first step is moving the employed bees onto the food resources and calculating their nectar amounts. Secondly, bees make a resource choice in accordance with the information they took from the employed bees and the nectar amount is calculated. In the last step, one of the employed bees is nominated randomly as a scout bee and it is sent to the sources to find new sources [30]. Half of the bees in the colony are appointed as employed and the rest half as onlooker bees in the algorithm [43]. Therefore, number of employed

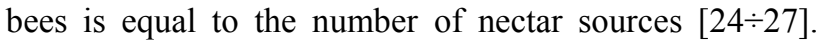
The employed bee becomes a scout when its food source has been exhausted by the bees. The food sources in the algorithm refer to the possible solutions of the problem to be optimized. The nectar amount belonging to a source means the quality value which is said by that source [24]. The flow chart of the $\mathrm{ABC}$ algorithm is given in Fig. 1 [28]. In the first step of the algorithm random solutions are produced in the interval of the variables $x i(i=1, \ldots$, $S$ ). Secondly, each employed bee discovers new sources whose amounts are equal to the half of the total sources. Eq. (8) is used to find a new source:

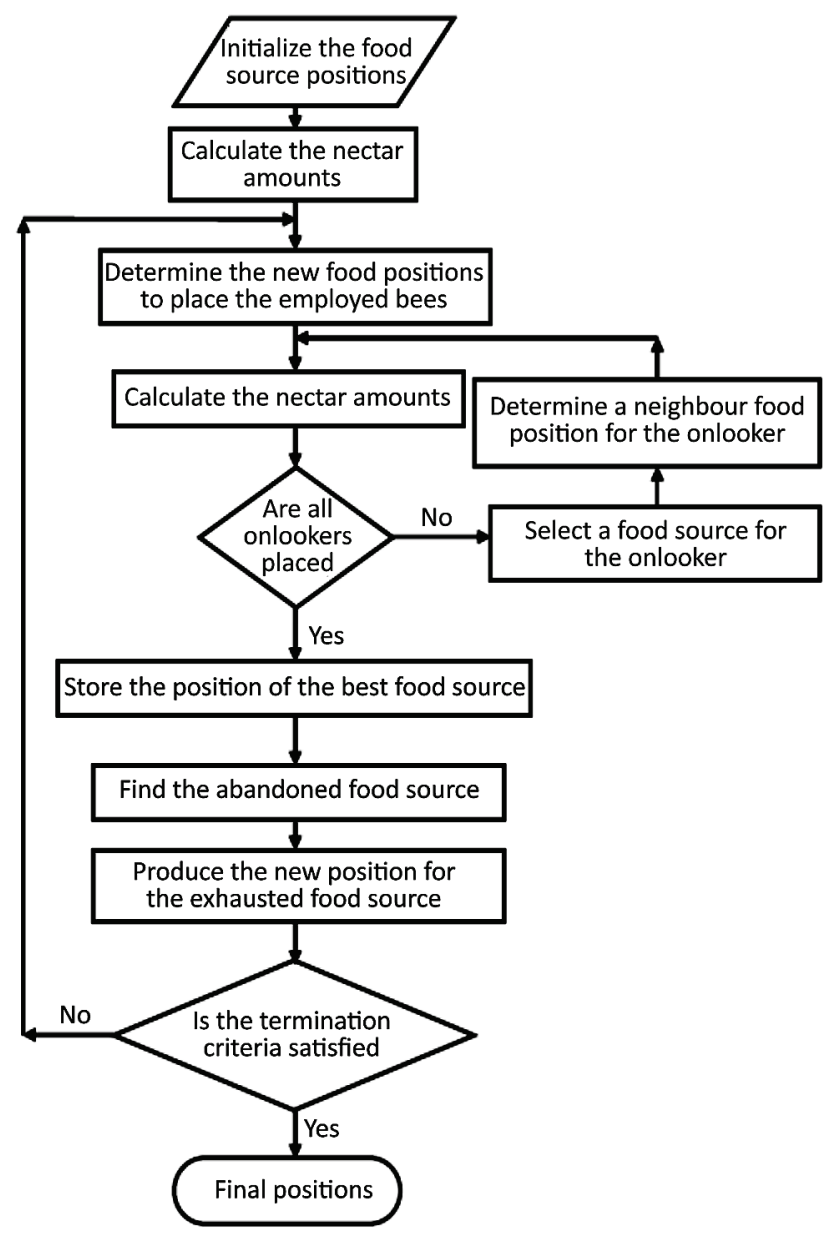

Figure 1 Flowchart of the $\mathrm{ABC}$ algorithm

$v_{i j}=x_{i j}+\varphi_{i j}\left(x_{i j}-x_{k j}\right)$.

In Eq. (8) $k$ is given by (int (rand $S)+1)$ and $j=1$, $\ldots, D$. After vector $\mathrm{v}_{\mathrm{i}}$ is generated, it is compared with the solutions of $x_{i}$ and the best one is selected. In the last step onlooker bees chose a food source with the possibility given in Eq. (9) where $P_{i}$ is the possibility of onlooker bees choosing a food source and $f_{i t}$ is the fitness function.

$$
P_{i}=\frac{f i t_{i}}{\sum_{j=1}^{s} f i t_{j}},
$$




$$
X_{i j}=x_{i \min }+\operatorname{rand} * X\left(x_{j \max }-x_{j \min }\right) .
$$

Scout bees do not use any pre knowledge while they are searching for nectar sources, but they absolutely do their researches randomly [28]. The scout bees are chosen among the employed bees. This selection is done with respect to the limit parameter. If a solution that represents a source is not realized with a certain number of trials, then this source is abandoned. The bee of that source goes to find new source as a scout bee. The number of comings and goings to a source is determined by the 'limit' parameter. Finding a new source of a scout bee is given in Eq. (10).

\section{Chaotic maps}

$\mathrm{ABC}$ algorithm has been inspired by the intelligent $\mathrm{A}$ chaotic map is a discrete-time dynamical system in the iteration form of:

$$
X_{i+1}=F\left(\boldsymbol{x}_{i}, Z\right) \text {. }
$$

where $Z$ is the control parameter, $\boldsymbol{x}$ is a vector and $F$ is a nonlinear transformation [34]. In this study Logistic map and Henon map are used.

\subsection{Logistic map}

The logistic map is a one-dimensional discrete-time non-linear system exhibiting quadratic non-linearity. The logistic map is given by the function

$$
f:[0,1] \rightarrow \mathfrak{R} \text { defined by } f(x)=\mu x(1-x),
$$

which is expressed in state equation form as :

$$
x_{i+1}=f\left(x_{i}\right)=\mu x_{i}\left(1-x_{i}\right), i=0,1,2, \ldots,
$$

where $x_{i} \in(0,1), x_{0}$ is not equal to $\{0,25 ; 0,5 ; 0,75\}$ and $\mu$ is set to 4 for ergodicity. $\mu$ is known as the control parameter or bifurcation parameter.

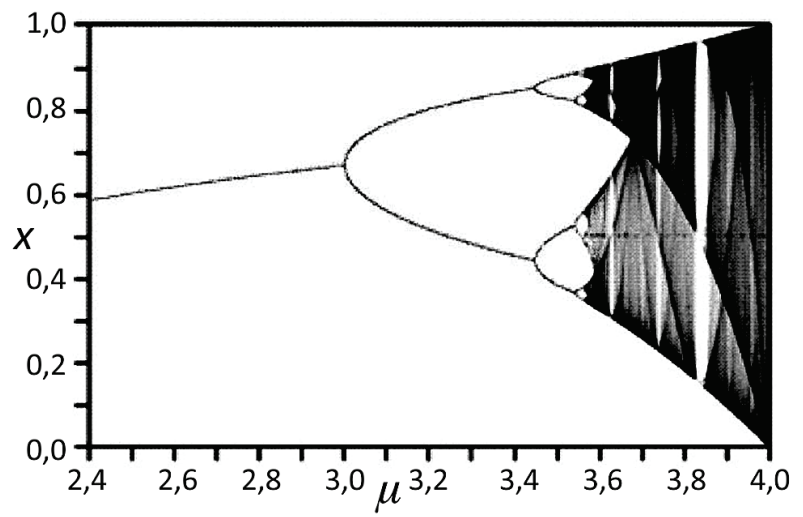

Figure 2 The bifurcation diagram of the logistic map

Here $x_{i}$ is the state of the system at time $i . X_{i+1}$ denotes the next state and i denotes the discrete time. The logistic

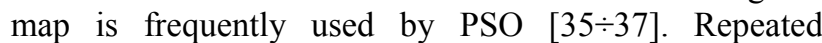
iteration of $f$ gives rise to a sequence of points $\left\{x_{i}\right\}$, known as an orbit. The bifurcation diagram of the logistic map is shown in Fig. 2. The chaotic numbers generated by logistic map are shown in Fig. 3.

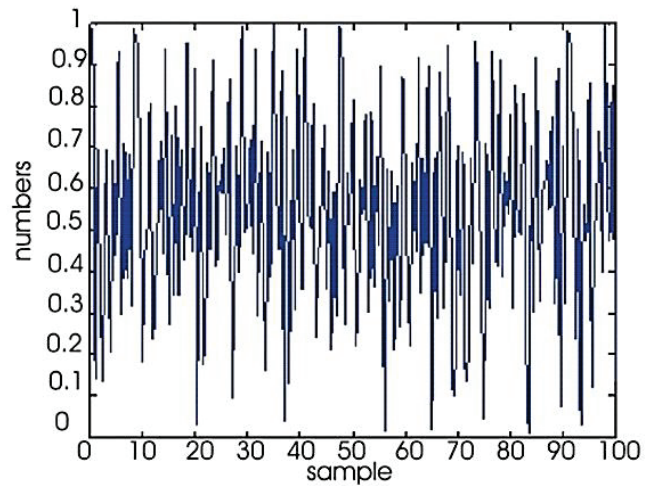

Figure 3 The chaotic numbers generated by logistic map

\subsection{Henon map}

Henon map is a two dimensional dynamical system, that is the simplified version of the Lorenz system [38]. The Henon equations are given by

$$
\begin{aligned}
& x_{i+1}=1+y_{i}-a x_{i}^{2}, \\
& y_{i+1}=b x_{i} .
\end{aligned}
$$

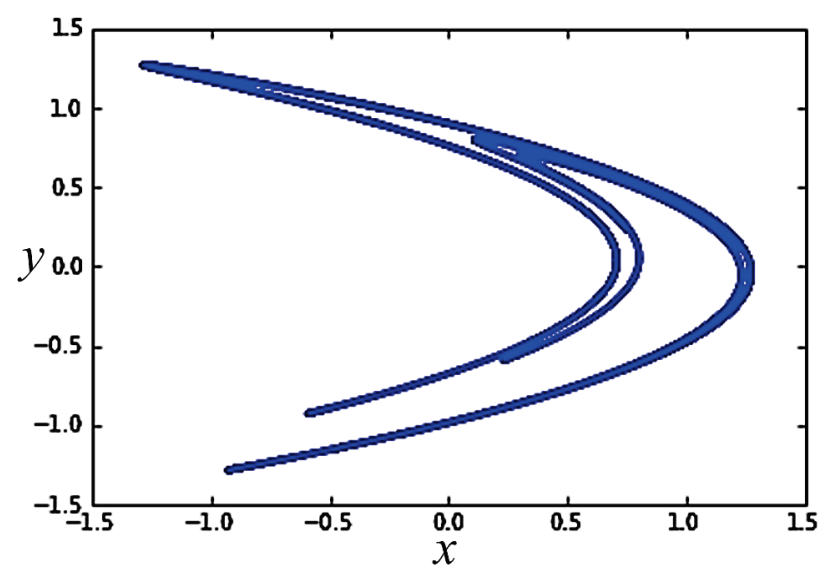

Figure 4 Henon map for $a=1,4$ and $b=0,3$

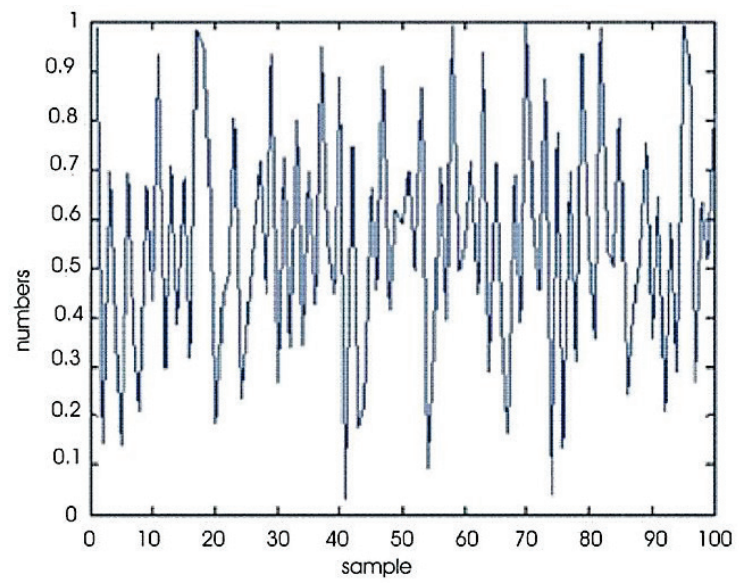

Figure 5 The chaotic numbers generated by Henon map

The Henon map has a strange attractor for $a=1,4$ and $b=0,3$ values. The Henon map used in this study is 
shown in Fig. 4. The chaotic numbers generated by logistic map are shown in Fig. 5.

\section{Chaotic Artificial Bee Colony}

Chaotic behavior refers to one type of complex dynamical behaviour that possesses some very special features such as being extremely sensitive to tiny variations of initial conditions. Chaotic systems exhibit irregular, unpredictable behavior. The boundary between linear and chaotic behavior is often characterized by period doubling, followed by quadrupling, etc., although other routes to chaos are also possible. Typically chaotic motions result when the system operating at a stable periodic orbit undergoes a series of bifurcations leading to the birth of a strange attractor under some parametric variations [42].

In simulating complex phenomena, sampling, numerical analysis, decision making and especially heuristic optimization needs random sequences with a long period and good uniformity (Coelho \& Mariani, 2008; Schuster, 1988)[32].

The chaotic map can be helpful to escape from a local minimum [39], and it can also improve the global/local searching capabilities. Randomly initializing of $\mathrm{ABC}$ and the limit parameter that is adjusted in initialization step that cannot be changed during new iterations may affect the algorithm performance on convergence speed. The use of chaotic sequences in $\mathrm{ABC}$ can be helpful to escape more easily from local minima than can be done through the classical ABC.[43]

Chaos can be applied to $\mathrm{CABC}$ in various ways. In this study, the chaotic maps such as logistic map and Henon map are used against the random number generator. Initial artificial colony is generated by iterating the selected chaotic maps until reaching the colony size as shown in Fig. 6. $\mathrm{N}$ is the dimension for the problem; $i$ is the colony member; and $j$ is the dimension. $x_{i, j}$ is the $j^{\text {th }}$ dimension of the ith colony member [33].

$$
\begin{aligned}
& i=0 \\
& \text { Do } \\
& \quad \begin{array}{l}
\text { Randomly initialize the first chaotic variable } \\
j=0
\end{array} \\
& \text { Do }
\end{aligned}
$$

Generate chaotic variable $c r_{i j}$ according to the chaotic maps given.

$$
X_{i j}=x_{i \min }+c r_{i j} X\left(x_{j \max }-x_{j \min }\right)
$$

While $j<$ Number of Employed Bee $i=i+1$

While $i \leq$ Colony size

$$
\text { Figure } 6 \text { Pseudo-code of } \mathrm{CABC} \text { change to orginal } \mathrm{ABC}
$$

\section{Simulation and results}

The CABC algorithm has been applied first on IEEE- 6 and second on IEEE-30 bus systems to minimize the active power loss. The IEEE- 6 bus system is shown in Fig. 7.

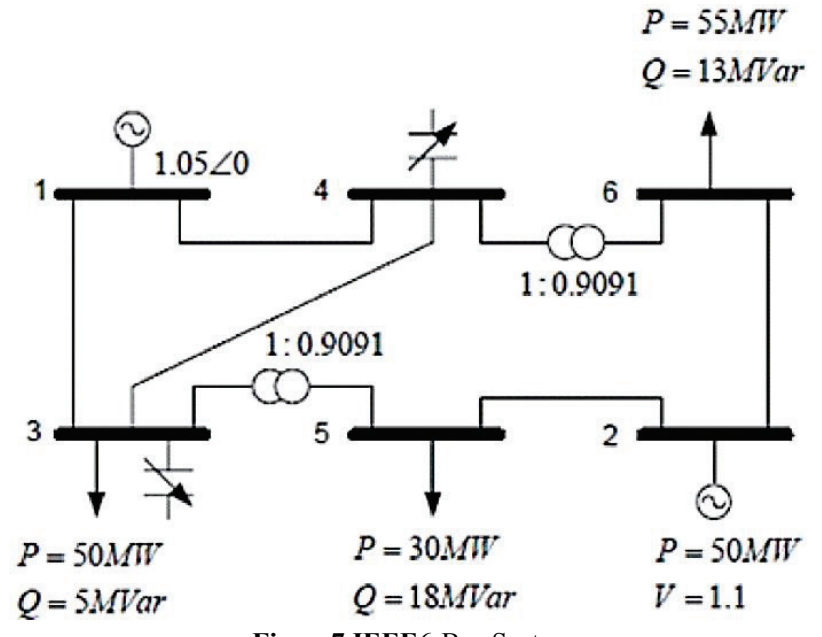

Figure7 IEEE6-Bus System

The line information of the system is shown in Tab. 1. The bounds of the variables are given in Tab. 2. The first bus is the oscillation bus, the second bus is the generator bus and the others are the charge buses.

Table 1 Line Information of the IEEE-6-BUS Test System (100 MVA

\begin{tabular}{|c|c|c|c|c|}
\hline \multicolumn{5}{|c|}{ Considered as base) } \\
\hline Bus Number & \multicolumn{2}{|c|}{ Impedance $(\mathrm{pu})$} & \\
\hline from & to & $R$ & $X$ & tap setting \\
\hline 1 & 3 & 0,123 & 0,518 & \\
\hline 1 & 4 & 0,080 & 0,370 & \\
\hline 4 & 3 & 0,097 & 0,407 & \\
\hline 3 & 5 & 0,000 & 0,003 & 0,9756 \\
\hline 5 & 2 & 0,282 & 0,640 & \\
\hline 2 & 6 & 0,723 & 1,050 & \\
\hline 4 & 6 & 0,000 & 0,133 & 0,9091 \\
\hline
\end{tabular}

The objective function for the Active power loss problem is given by Eq. (1). The Active and reactive power balances of the variables denoting the constraints are shown in Eqs. (2) and (3). Additonally Tab. 2 constitutes the constraints of the variables. The values of the $\mathrm{CABC}$ algorithm are as follows: Colony Dimension $=20$, Maximum number of cycles $=500$, Number of variables $=5$, Limit parameter $=3000$.

Table 2 Rpo Variable Bounds

\begin{tabular}{|c|c|c|c|c|c|}
\hline & \multicolumn{2}{|c|}{ Tap } & Voltage(pu) & \multicolumn{2}{c|}{$\begin{array}{c}\text { Reactive Power } \\
\text { Supply(MVAR) }\end{array}$} \\
\hline & & & Generator & \multicolumn{2}{c|}{ Capacitor } \\
\hline & T35 & T46 & V2 & Q3 & Q4 \\
\hline $\min$ & 0,91 & 0,91 & 1,10 & 0 & 0 \\
\hline $\max$ & 1,11 & 1,11 & 1,15 & 5 & 5,5 \\
\hline
\end{tabular}

Variables given in Tab. 2 refer to the nectar position and the active power losses refer to nectar amount. Fig. 8 illustrates the changes in active power loss based on Cycles for the IEEE-6 bus system obtained by classical ABC [40] whereas Figs. 9 and 10 illustrate the changes obtained by $\mathrm{CABC}$ algorithm using Henon and Logistic map respectively. Tab. 3 shows the result minimal active power loss values of IEEE-6 bus system for the ABC, $\mathrm{CABC}-$ Henon and CABC-Logistic.

Tab. 3 shows the result minimal active power loss values of IEEE- 6 bus system for the $\mathrm{ABC}, \mathrm{CABC}-H e n o n$ and CABC-Logistic. The best solution is 8,4891 (MW) which is found with $\mathrm{CABC}$ algorithm using Henon map. 


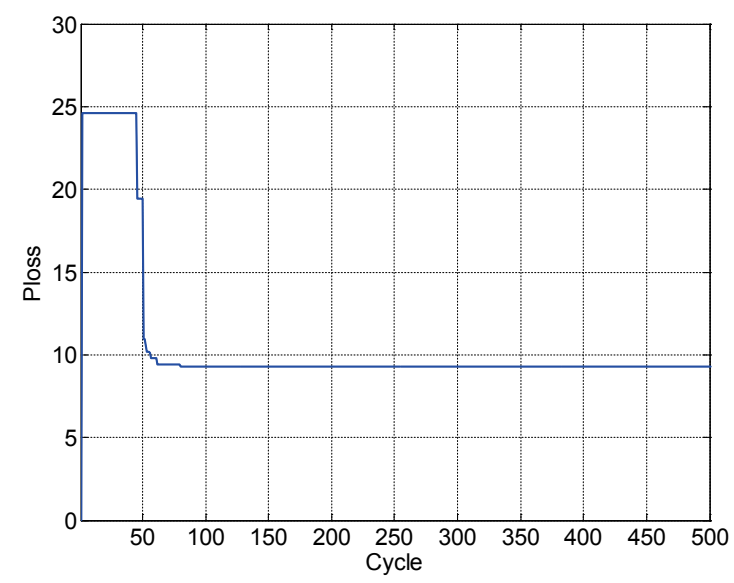

Figure 8 Active Power Loss Values with ABC Algorithm for IEEE-6 Bus System

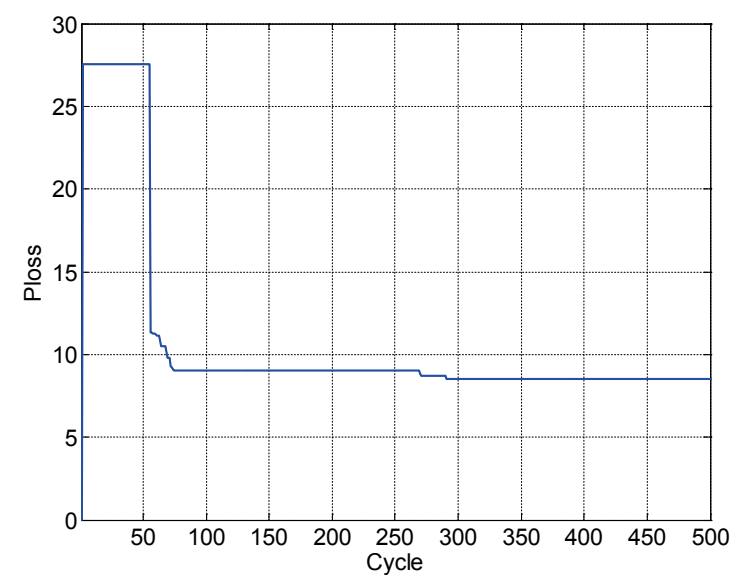

Figure 9 Active Power Loss Values with CABC Algorithm using Henon Map for IEEE-6 Bus System

To prove the effectiveness and robustness of the CABC algorithm it has been applied on the IEEE-30 bus system shown in Fig. 11. It consists of six generator buses, twenty four load buses, and forty one transmission lines of which four branches. Details are given in table VI. Fig. 12 illustrates the changes in active power loss based on Cycles for the IEEE-30 bus system obtained by classical ABC [33] and Figs. 13 and 14 illustrate the changes in active power loss based on Cycles for the IEEE-30 bus system obtained by CABC algorithm using Henon and Logistic map respectively.

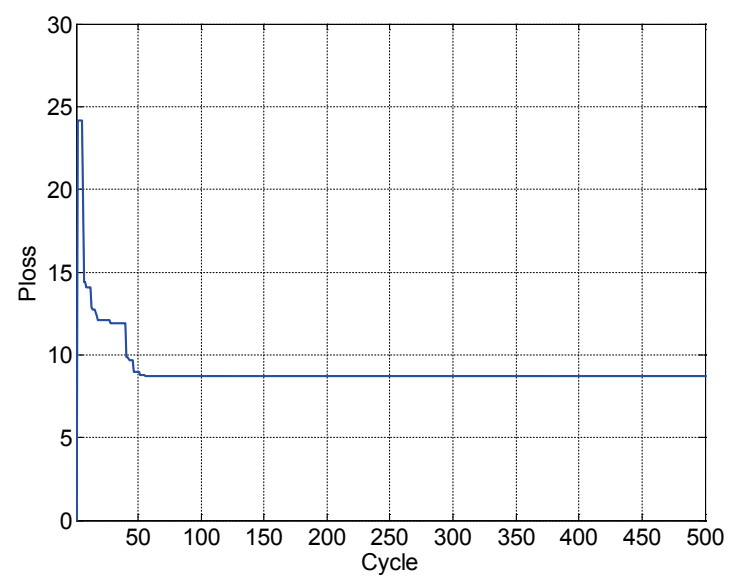

Figure 10 Active Power Loss Values with CABC Algorithm using Logistic Map for IEEE-6 Bus System

Table 3 Result Minimal Active Power Loss Values of IEEE-6 Bus System for the ABC, CABC-Henon and CABC-Logistic

\begin{tabular}{|c|c|c|}
\hline \multicolumn{3}{|c|}{ IEEE-6 BUS SYSTEM } \\
\hline \multicolumn{3}{|c|}{ ACTIVE POWER LOSS VALUES (MW) } \\
\hline ABC & CABC Henon & CABC Logistic \\
\hline 8,6203 & 8,4891 & 8,5046 \\
\hline
\end{tabular}

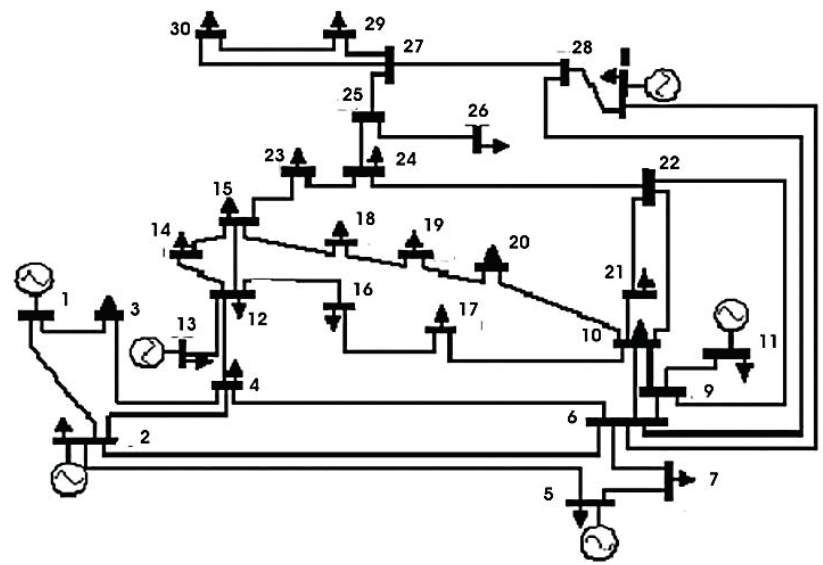

Figure 11 IEEE 30-Bus System

Tab. 5 shows the result minimal active power loss values of IEEE-30 bus system for the ABC, CABCHenon and CABC-Logistic. The best solution is 4,4325 (MW) which is found with $\mathrm{CABC}$ algorithm using Logistic map.

Table 4 IEEE 30Bus System Variable Bounds

\begin{tabular}{|c|c|c|c|c|c|c|c|c|c|c|c|c|c|c|}
\hline & \multicolumn{4}{|c|}{ Limit Values of Generator Voltages $(\mathrm{pu})$} & \multicolumn{4}{c|}{$\begin{array}{c}\text { Regulation Limit Values of Tap } \\
\text { Setting Transformers }\end{array}$} & \multicolumn{4}{c|}{$\begin{array}{c}\text { Reactive Power Limit Values of } \\
\text { Compensators (pu) }\end{array}$} \\
\hline & V1 & V2 & V5 & V8 & V11 & V13 & T4-12 & T6-9 & T6-10 & T27-28 & QC10 & QC15 & QC19 & QC24 \\
\hline $\min$ & 1 & 1 & 1 & 1 & 1 & 1 & 0,9 & 0,9 & 0,9 & 0,9 & 0 & 0 & 0 & 0 \\
\hline $\max$ & 1,1 & 1,1 & 1,1 & 1,1 & 1,1 & 1,1 & 1,1 & 1,1 & 1,1 & 1,1 & 0,05 & 0,05 & 0,05 & 0,05 \\
\hline
\end{tabular}

Table 5 Result Minimal Active Power Loss Values of IEEE-30 Bus System for the ABC, CABC-Henon and CABC-Logistic

\begin{tabular}{|c|c|c|}
\hline \multicolumn{3}{|c|}{ IEEE-30 BUS SYSTEM } \\
\hline \multicolumn{3}{|c|}{ ACTIVE POWER LOSS VALUES (MW) } \\
\hline ABC & CABC Henon & CABC Logistic \\
\hline 4,8368 & 4,4325 & 4,4323 \\
\hline
\end{tabular}

It can be seen from Tabs. 4 and 5 that CABC algorithm using chaotic maps can produce better solutions than that of classical $\mathrm{ABC}$ algorithm method. 


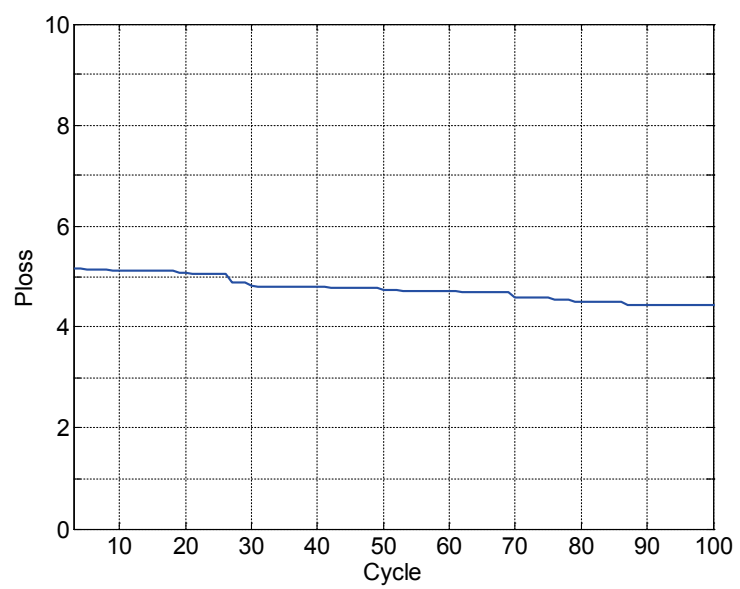

Figure 12 Active Power LossValues with ABC Algorithm for IEEE-30 Bus System

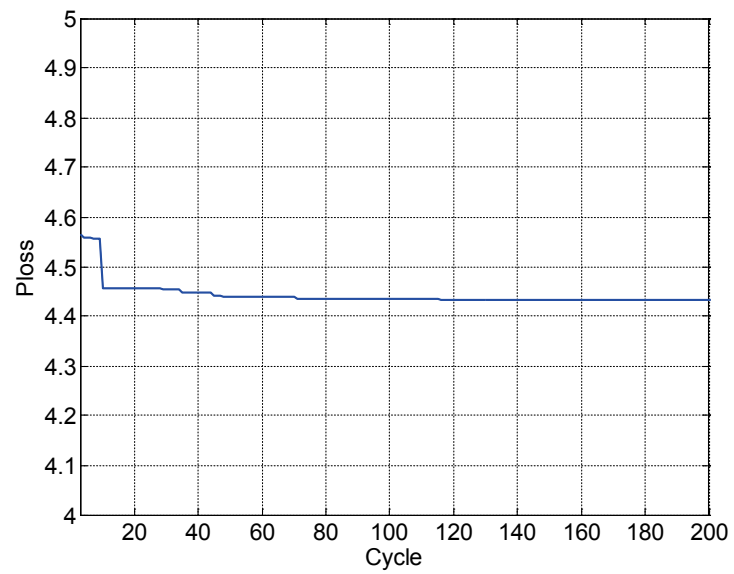

Figure 13 Active Power Loss Values with CABC Algorithm using Henon Map for IEEE-30 Bus System

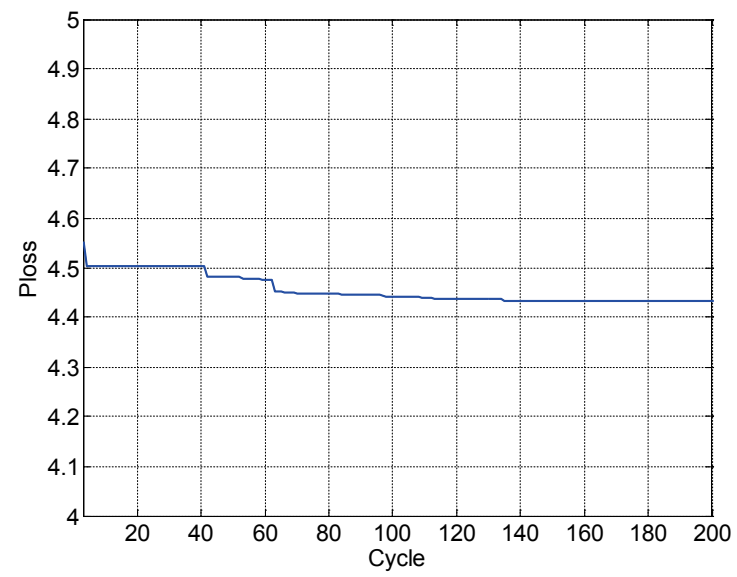

Figure 14 Active Power LossValues with CABC Algorithm using Logistic Map for IEEE-30 Bus System

\section{Conclusion}

In this study, a new approach to RPO is presented by using $\mathrm{CABC}$ algorithm. CABC algorithm based on using chaotic number generators such as Logistic map and Henon map, has been successfully applied to IEEE-6 bus and IEEE-30 bus power systems to minimize the active power loss. The results compared with the classical ABC show that $\mathrm{CABC}$ algorithm also reaches the active power loss limits and improves markedly the quality of results.
Simulation results are encouraging and show the succes of the applied approach.

\section{References}

[1] Lu, Z.; Ma, L. Power System Reactive Power Optimization Based on Direct Neural Dynamic Programming. // Proceedings of the $3^{\text {rd }}$ International Conference on Intelligent System and Knowledge Engineering, Xiamen, 2008, pp. 862-866.

[2] Durairaj, S.; Fox, B. Evolutionary Computation Based Reactive Power Optimization. // IET-UK International Conference on Information and Communication Technology in Electrical Sciences (ICTES 2007), Chennai Tamilnadu, India 2008, pp. 120-125.

[3] Hazral, J.; Sinha, A. K. A Study on Real and Reactive Power Optimization using Particle Swarm Optimization. // Second International Conference on Industrial and Information Systems, ICIIS 2007, Penadediya 8 - 11 August 2007, Sri Lanka, pp. 323-328.

[4] Dan, L.; Liqun, G.; Shun, L.; Jia, M.; Yang, L. Adaptive Particle Swarm Optimization Algorithm for Power System Reactive Power Optimization. // Proceedings of the 2007 American Control Conference Marriott Marquis Hotel at Times Square New York City, USA, July 11-13, 2007.

[5] Wei, H.; Chunli, X.; Jianhua, Z.; Shanang, H. Study of Reactive Power Optimization Based on Immune Genetic Algorithm. // Transmission and Distribution Conference and Exposition, 2003 IEEE PES. vol. 1, Sept. 2003, pp. 186-190.

[6] Chen, Y.; Zhang, Y.; Wei, Y. Application of Improved Genetic Algorithm Combining Sensitivity Analysis to Reactive Power Optimization for Power System. // The $3^{\text {rd }}$ international conference on deregulation and restructuring and power technologies (DRPT 2008), 6-9 April 2008, Nanjing China, pp.798-803.

[7] Wang, C.; Cheng, H. Z.; Yao, L. Z. Reactive Power Optimization by Plant Growth Simulation Algorithm. // The $3^{\text {rd }}$ International Conference on Deregulation and Restructuring and Power Technologies (DRPT 2008), 6-9 April 2008, Nanjing China, pp.771-774.

[8] Ai, X.; Yang, J.; Xie, S. The Research on the Hybrid Intelligent Algorithm to Reactive Power Optimization. // The 3rd İnternational Conference on Deregulation and Restructuring and Power Technologies (DRPT 2008), 6-9 April 2008, Nanjing China, pp.1009-1013.

[9] Wei, H.; Cong, Z.; Jingyan, Y.; Jianhua, Z.; Zifa, L.; Zhilian, W.; Dongli, P. Using Bacterial Chemotaxis Method for Reactive Power Optimization. // Transmission and Distribution Conference and Exposition, Chicago, IL, 2008, pp. 1-7.

[10] Zhang, X.; Chen, W.; Dai, C. Application of Oriented Search Algorithm in Reactive Power Optimization of Power System. // The $3^{\text {rd }}$ International Conference on Deregulation and Restructuring and Power Technologies (DRPT 2008), 6-9 April 2008, Nanjing China, pp. 28562861

[11] Liu, H.; Hou, Y.; Chen, X. A Hybrid Algorithm of Ordinal Optimization and Tabu Search for Reactive Power Optimization in Distribution System. // The $3^{\text {rd }}$ International Conference on Deregulation and Restructuring and Power Technologies (DRPT 2008), 6-9 April 2008, Nanjing China, pp. 1318-1324.

[12] Liu, Z.; Zhao, D.; Zhang, X.; Dan, B.; Guan, F. Reactive Power Optimization in Power System Based on Chaos Ant Colony Algorithm. // Sustainable Power Generation and Supply, 2009. SUPERGEN '09. International Conference, Nanjing, April 2009, pp.1-4 
[13] Lenin, K.; Mohan, M. R. Ant Colony Search Algorithm for Optimal Reactive Power Optimization. // Serbian Journal of Electrical Engineering. 3, 1(2006), pp. 77-88. DOl: 10.2298/SJEE0601077L

[14] Liu, K.; Sheng, W.; Li, W.; Li, Y. Research on Reactive Power Optimization based on Adaptive Genetic Simulated Annealing Algorithm. // Lecture Notes in Computer Science. (2006), pp. 600-611. DOI: 10.1007/11816157_72

[15] Zhang, W.; Liu, Y. Fuzzy Logic Controlled Particle Swarm for Reactive Power Optimization Considering Voltage Stability. // The $7^{\text {th }}$ International Power Engineering Conference IPEC, Singapore, 2005. pp. 551-555.

[16] Xiangzheng, X. Research on Reactive Power Optimizing Control Based on Immune Algorithms. // The Eighth International Conference on Electronic Measurement and Instruments ICEMI, Xi'an. 3, (2007), pp. 898-901. DOI: 10.1109/icemi.2007.4351062

[17] Chettih, S.; Khiat, M.; Chaker, A. Means Optimization of Reactive Power Compensation Using the Particle Swarm Optimization PSO Method: Application in the Western Algerian Transmission System. // International Review of Electrical Engineering. 4, 4(2009), pp. 622-626.

[18] Laouafi, F.; Boukadoum, A.; Leulmi, S. Reactive Power Dispatch with Hybrid Formulation: Particle Swarm Optimization and Improved Genetic Algorithms with Real Coding. // International Review of Electrical Engineering. 5, 2(2010), pp. 601-607.

[19] Rahiel, D.; Mounir, K.; Chaker, A.; Haimour, R. Reactive Power Optimization in Transmission Power System Using Interior Point Method. // International Review of Electrical Engineering. 5, 2(2010), pp. 614-618.

[20] Khorsand, M. A.; Heydari, H. Multiobjective Augmented Epsconstraint Optimization for Economic/Environmental Stochastic Unit Commitment in Power Systems with High Penetration of Wind Power. // International Review of Electrical Engineering. 5, 4(2010), pp. 1685-1694.

[21] Karaboga, D.; Bastürk, B. A powerful and efficient algorithm for numerical function optimization: artificial bee colony (ABC) algorithm. // J Global Optim. 39, 3(2007), pp. 459-471. DOI: 10.1007/s10898-007-9149-x

[22] Karaboga, D.; Bastürk, D.; Bastürk, B. On the performance of artificial bee colony (ABC) algorithm. // Applied Soft Computing. $\quad 8, \quad 1(2008)$, pp. 687-697. DOI: 10.1016/j.asoc.2007.05.007

[23] Karaboga, D.; Bastürk, B. Artificial bee colony (ABC) optimization algorithm for solving constrained optimization problems. // Foundations of Fuzzy Logic and Soft Computing, Springer-Verlag, Berlin. 4529, (2007), pp. 789798.

[24] Karaboğa, N. A new design method based on artificial bee colony algorithm for digital IIR filters. // Journal of the Franklin Institute. 346, (2009), pp. 328-348. DOI: 10.1016/j.jfranklin.2008.11.003

[25] Rao, R. S.; Narasimham, S. V. L.; Ramalingaraju, M. Optimization of Distribution Network Configuration for Loss Reduction Using Artificial Bee Colony Algorithm. // World Academy of Science, Engineering and Technology. 45, (2008).

[26] Sabat, S. L.; Udgata, S. K.; Abraham, A. Artificial bee colony algorithm for small signal model parameter extraction of MESFET. // Engineering Applications of Artificial Intelligence, Elsevier. (2010), pp. 1-6.

[27] Kang, F.; Li, J.; Xu, Q. Structural inverse analysis by hybrid simplex artificial bee colony algorithms. // Computers and Structures. 87, (2009), pp. 861-870. DOI: 10.1016/j.compstruc.2009.03.001

[28] Quan, H.; Shi, X. On the Analysis of Performance of the Improved Artificial Bee Colony Algorithm. // Forth International Conference on Natural Computation. (2008), pp. 654-658. DOI: 10.1109/icnc.2008.211
[29] Bao, L.; Zeng, J. Comparison and Analysis of the selection Mechanism in the Artificial Bee Colony Algorithm. // Ninth International Conference on Hybrid Intelligent Systems, Shenyang. (2009), pp. 411-416. DOI: 10.1109/his.2009.319

[30] Singh, A. An artificial bee colony algorithm for the leaf constrained minumum spanning tree problem. // Applied Soft Computing. (2009). DOI: 10.1016/j.asoc.2008.09.001

[31] Alatas, B.; Akin, E.; Ozer, B. Chaos embedded particle swarm optimization algorithms. Chaos, Solitons \& Fractals. (2009). DOI: 10.1016/j.chaos.2007.09.063.

[32] Coelho, L. S.; Mariani, V. C. Use of chaotic sequences in a biologically inspired algorithm for engineering design optimization. // Expert Systems with Applications. 34, (2008), pp. 1905-1913. DOl: 10.1016/j.eswa.2007.02.002

[33] Alatas, B. Chaotic bee colony algorithms for global numerical optimization. // Expert Systems with Applications. 37, (2010), pp. 5682-5687. DOI: 10.1016/j.eswa.2010.02.042

[34] Thompson, J. M. T.; Stewart, H. B. Nonlinear Dynamics and Chaos, John Wiley \& Sons $2^{\text {nd }}$ Edition, 2002.

[35] Liu, B.; Wang, L.; Jin, Y. H.; Huang, C. X. Designing Neural Networks Using Hybrid Particle Swarm Optimization. // Lecture Notes in Computer Science. 3496, (2005), pp. 391-397. DOl: 10.1007/11427391_62

[36] Meng, H. J.; Zheng, P.; Wu, R. Y.; Hao, X. J.; Xie, Z. A hybrid particle swarm algorithm with em-bedded chaotic search. // Proc. IEEE Conference on Cybernetics and Intelligence Systems. (2004), pp. 367-371.

[37] Chen, A. L.; Wu, Z. M.; Yang, G. K. LS-SVM based on chaotic particle swarm optimization with simulated annealing. // Lecture Notes in Computer Science. 3959, (2006), pp. 99-107. DOI: 10.1007/11750321_9

[38] He'non, M. A two-dimensional mapping with a strange attractor. // Commun Math Phys. 50, (1976), pp. 69-77. DOI: 10.1007/BF01608556

[39] Coelho, L. S.; Mariani, V. C. A novel chaotic particle swarm optimization approach using Henon map and implicit filtering local search for economic load dispatch. // Chaos, Solitons and Fractals. 39, (2009), pp. 510-518. DOl: 10.1016/j.chaos.2007.01.093

[40] Çobanli, S.; Öztürk, A.; Güvenç, U.; Tosun, S. Active Power Loss Minimization in Electric Power Systems Through Artifiial Bee Colony Algorithm. // I.R.E.E. 5, 5(2010), September-October.

[41] Kuru, L.; Kuru, E.; Yalcin, M. A. An application of chaos and bifurcation in nonlinear dynamical power systems. // The $2^{\text {nd }}$ International IEEE Conference on Intelligent Systems Proceedings, IS-04, 2004.

[42] Alatas, B. Chaotic bee colony algorithms for global numerical optimization. // Expert Systems with Applications. 37, 8(2010), pp. 5682-5687. DOl: 10.1016/j.eswa.2010.02.042

[43] Ravi, V. Effective optimization technique for power system stabilization using Artificial Bee Colony. // International Conference on Computer Communication and Informatics 01/2012.

\section{Authors' addresses}

Leyla Kuru, Ass. Prof

Düzce University Computer Engineering

Konuralp-Düzce-Turkey

E-mail: leylakuru@duzce.edu.tr

Ali Ozturk, Ass. Prof

Düzce University Electrical \& Electronical Engineering

Konuralp-Düzce-Turkey

E-mail: aliozturk@duzce.edu.tr 
Ersen Kuru, Ass. Prof

Düzce University Mechatronics Engineering

Konuralp-Düzce-Turkey

E-mail: ersenkuru@duzce.edu.tr

Serkan Cobanli

Düzce-Turkey

E-mail: serkancobanli@hotmail.com 